\title{
CHILD MARRIAGE: A MAJOR RISKY BEHAVIOR IN DEVELOPING EGYPTIAN GOVERNORATES
}

\author{
By
}

\author{
Dalia G. Sos , Maha M. El-Gaafary, Maha M. Wahdan, Ghada O. \\ Wassif, Sally A. Hakim, Wafaa M. Hussein , Amr Hassan*, Mohammed \\ Y. El-Awady, Mervat H. Rady, Wagida A.
}

Department of Community, Environmental and Occupational Medicine, Faculty of Medicine, Ain Shams University and *the National Population Council

Correspondence: Dalia Gaber Sos

E-mail: daliagabesos@gmail.com

\begin{abstract}
Background: Marriage timing is one of the important determinants of birth rates and health profile of both the mothers and infants. Child marriage is recognized as a major development issue that affects girls in many developing countries. The practice has been linked to a number of health risks, higher fertility, and lower education attainment.

Objective: To estimate the rate of child marriage in some underdeveloped Egyptian governorates and identify its correlates.

Subjects and Methods: The study was part of a large survey, which was conducted in six purposefully selected Egyptian governorates and defined as developing; three from upper Egypt (Sohag, Assuit and Menia) and three from lower Egypt (Sharkia, Behira and Ismalia) aiming to measure the prevalence of child marriage and assess the impact of the different social and economic factors that affect the occurrence of the phenomena. Data were collected from 15279 females using an interview questionnaire targeting households' members (sampling unit) in the selected governorates.

Results: Prevalence of early age of marriage was significantly high among governorates of upper Egypt than in lower Egypt (reaching 39.75 in rural areas in El Menia) especially in rural residency. Lower educational level (less than secondary School) and consanguinity were found to have significant association with early age of marriage. Results revealed that early age of marriage has its effect on birth rate with mean number of children of 3.59 per women who married at age less than 18 years.
\end{abstract}

Conclusion: Early age of marriage is an important public health challenge. Hence, a national multi-sectorial approach must be targeted to reduce this phenomenon.

Key words: child marriage - rural - upper Egypt- socio-economic impact.

\section{INTRODUCTION}

Marriage is one of the important social pillars that affect the structure of the population. Timing of marriage has its major effects on birth rates and health profile of both the mother and infant (Elden and Mosleh, 2015).
Early marriage, also referred to as child marriage, is defined by UNICEF as any marriage carried out below the age of 18 years, before the girl are physically mature and psychologically developed, and become ready to carry the 
responsibilities of the marriage and child bearing (WCLRF , 2008).

Financial incentives encourage parents to accept the marriage of their daughters, while they are still children: to ensure their daughter's financial security and to relieve the financial burden daughters place on the family (e.g., Feeding, clothing, and education). Most of these marriages are arranged by parents. Some families take advantage of religious laws that prohibit an earlier marriage age, and arrange for their daughters to marry in religious wedding ceremonies, postponing the official registration until the bride reaches the legal age. Such practices leave bride with no legal basis to receive inheritance, alimony, or child support if the husband dies prematurely or abandons his underage bride (Farid et al., 2015).

Child marriage is recognized as a major developmental issue that affects girls in many developing countries. The practice has been linked to a number of health risks: higher fertility, and lower education attainment. The negative impact of child marriage on girl's health, education, and well-being is often profound when the girl marries very early; for example, it is known to have a negative impact on school enrollment and attainment. The earlier a girl marries, the more likely she drops school classes early and thereby has a low level of education attainment limiting her employment and earnings potential for the rest of her life (Malé and Wodon, 2016). The negative impact of child marriage on a wide range of development outcomes explains why in many countries, child marriage is now prohibited by law, and why the elimination of child marriage is part of the new Sustainable Development Goals (UNFPA, 2012).

Previous study indicated that $48 \%$ of women between 15 and 24 were married before 18 in South Asia, 42\% in Africa , and more than $60 \%$ in some parts of East and West Africa, while only $29 \%$ were married before the age of 18 years, in America and the Caribbean, though some individual countries have much higher rates (UNICEF, 2005), early marriage is prevalent in the Middle East, where almost $50 \%$ of girls younger than 18 in Yemen and Palestine are married (UNFPA, 2005).

According to the Egyptian law, the right to marry is defined by a series of conditions, namely the requirement of the spouses consent for the marriage to be valid; the existence of a minimum required age for marriage; and the obligation to officially register the marriage. The absence of these conditions amounts to a violation of the right to marry or not (WCLRF, 2008).

While marriage is considered a choice, Egyptian laws clearly sets age of marriage to be 18 years for both sexes. Child marriage is recognized as a human right violation on both the national and the international levels (Malé and Wodon, 2016).

Early marriage is perpetuated in areas of poverty, more common in rural communities (UNFPA, 2012).In Egypt, based on DHS 2014, one in six women ages 18-22 marries below the age of 18 , and a smaller proportion do so before the age of 15 (Roudi-Fahimi and Ibrahim, 2013). 
The current study was conducted to assess the burden of the phenomena, which may differ in different geographical and cultural diverse in the Egyptian governorates. The overall objective is to ensure providing the necessary information to contribute to the modernization and development of population policies and strategies in line with the current situation in society aiming to preserve the health of mothers and the coming generation, in Egypt, through ensuring proper timing of marriage. The current study has been conducted to measure the prevalence of child marriage in the 6 selected underdeveloped governorates in upper and Lower Egypt and to assess the impact of the different social and economic factors that affect the adoption of this behavior.

\section{SUBJECTS AND METHODS}

The current study was nested from a survey implemented during the time period from May 2017 to September 2017. This survey was conducted in six purposefully selected Egyptian governorates: three from Upper Egypt (Sohag, Assuit and Menia) and three from Lower Egypt (Sharkia, Behira and Ismalia). They were previously identified to have underdeveloped socioeconomic and health indicators. The National Population Council (NPC) branch offices, in these governorates, supported the field work during data collection.

Sample size was calculated taking into account the nearest indicator to $50 \%$ (which is the use of family planning methods rate) that led to a larger sample size, taking into account the size of the population in the province. Hence total sample size in each governorate in Upper and Lower Egypt was 2000 households for the governorates: Beheira, Minya, Assiut and Sohag and 2500 for El Sharkia governorate and 600 only for Ismailia yielding a total of 15279 female participants at the $95 \%$ confidence level and 2\% margin of error and 2.0 Design Effect.

"Household" is defined as 2 or more persons living in one house and economically sharing a single comprehensive dwelling. All age groups and gender were included.

A sample from the Central Agency for Public Mobilization and Statistics (CAPMAS) representing the target governorates was used. The sample was presented as 100-125 clusters, where each cluster included a number of 20 family" household" defined by the name of the head of each family distributed according to geographical distribution in terms of rural and urban areas and centers, departments and villages and different districts according to the census of 2006.

A questionnaire was designed to fulfill different objectives of the survey that included child marriage and its different determinants in term of sociodemographic and economic factors.

The data were collected by nurses and Raadat Refeyat (rural field health care providers). They were supervised by the NPC team in the different governorates. Training sessions were conducted in all the six governorates to all the data collectors to ensure comprehensiveness and reduce the possibility of bias.

Detailed methods are cited in NPC report "Surveillance of Socio- 
demographic and health indicators in some Egyptian Governorates" 2017.

A pilot study was conducted in Bilbes city of El Sharkia governorate in order to; estimate the time required to complete the questionnaire, to reach the final version of the questionnaire that suits all literacy levels and to add the necessary instructions for data collectors to facilitate the field work task.

\section{Data Management and Statistical Analysis:}

Data collected from all the six targeted governorates were coded and entered on CSPro statistical program (Census and Survey Processing System).

The research team conducted several workshops to develop the final structure of the database on the program CSPro version 7.0 to ensure minimal data entry errors using validation rules and organize data in a way that allowed it to be used later as baseline for further NPC studies.

Statistical analysis was performed using SPSS version 24. For descriptive analysis, quantitative data were summarized in the forms of means \pm standard deviations or median and interquartile range (IQR). Qualitative data were presented in frequencies and percentages. Bar charts were used for graphical presentation of qualitative data. Qualitative variables were compared using Chi squared test. Means were compared between two groups using independent samples t test. Mann Whitney U test was used to compare medians between two groups. Odds Ratios (ORs) and 95\%
Confidence Intervals (95\% CI) were calculated. In generalized estimating equations, binary logistic regression was used to calculate adjusted ORs using inverse propensity score weighing. Pvalue $<0.05$ was considered significant. The data on household characteristics and household assets were used to create a wealth index. A subset of indicators common to both urban and rural areas was analyzed using "principal components analysis" to produce a "common factor score" for each household. In a second step, separate factor scores were produced for households in urban and in rural areas using area-specific indicators. Lastly, the separate area-specific factor scores were combined in a"combined wealth index" after adjusting the area-specific scores through regression on the common factor scores. Each member of a household was assigned the score for their household. The de jure household population was then divided into five equal parts, from quintile one (lowest-poorest) to quintile five (highest-wealthiest).

\section{Ethical Considerations:}

An approval was obtained from the ethical committee of Faculty of Medicine, Ain Shams University prior to conducting the study. Privacy and confidentiality were maintained according to the revised declaration of Helsinki on biomedical research ethics (WMA, 2013).

Competing interests: The authors declare that they have no competing interests. 


\section{RESULTS}

In this study, 15279 women aged 15-49 years were interviewed. All governorates were equally represented except for Ismailia, which constituted only $5.2 \%$ of the sample. Among ever married women, the percentage of marriage before the age of 18 ranged between a lowest of $11.71 \%$ in urban areas in Ismailia, and a highest of $39.74 \%$ in rural areas in Menya (Figure
1). The study found that percentage of marriage before the age of 18 was highest in older age groups (45 years and above especially in El Menya and Sohag reaching $47.58 \%$ and $35.22 \%$ respectively) than in younger age groups (15 years and above as well as 20 years and above) (Table1).

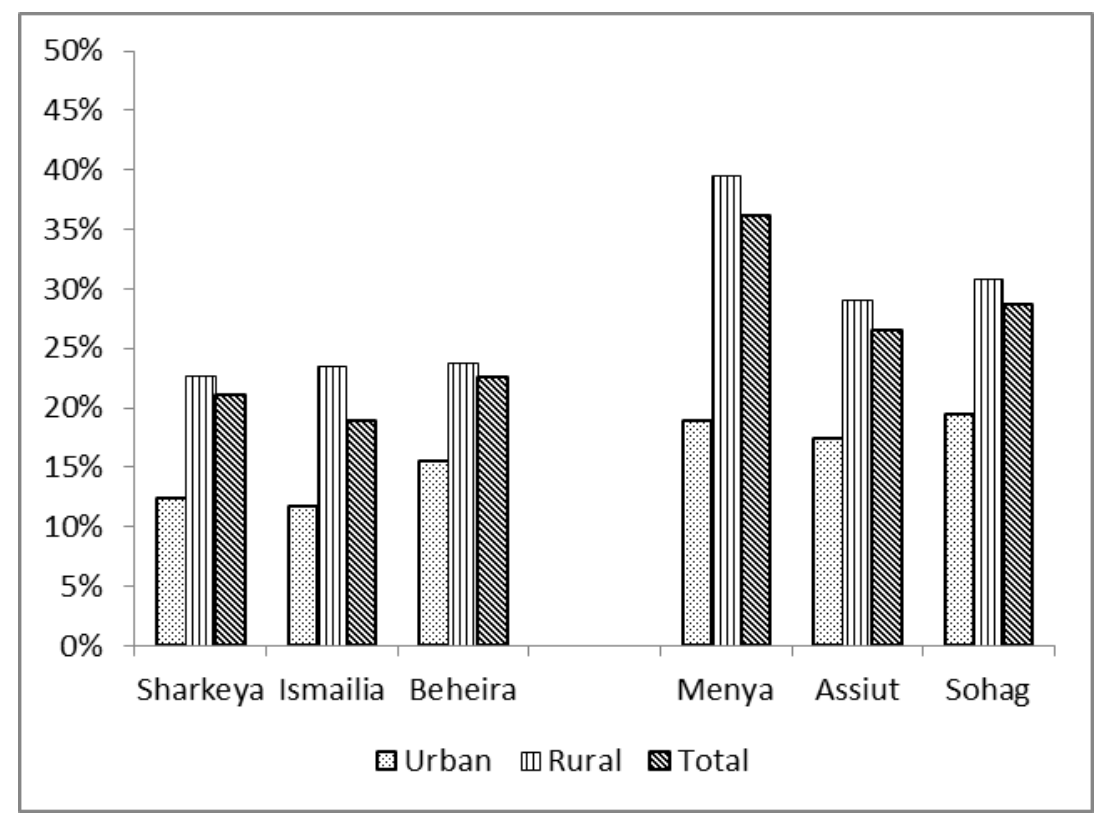

Figure( 1): Percentage of women married before the age of 18 out of all ever married women aged $15-49$

Table(1): Percentage of child marriage by 5 year age groups in 6 governorates (as a percentage of all women in each age group)

\begin{tabular}{|l|c|c|c|c|c|c|}
\hline Age groups & Sharkeya & Ismailia & Beheira & Menya & Assiut & Sohag \\
\hline $15-$ & $\mathbf{4 . 2 7 \%}$ & $\mathbf{7 . 6 4 \%}$ & $\mathbf{1 0 . 1 0 \%}$ & $\mathbf{7 . 2 3 \%}$ & $\mathbf{4 . 3 9 \%}$ & $\mathbf{7 . 3 1 \%}$ \\
\hline $20-$ & $\mathbf{1 0 . 4 5 \%}$ & $\mathbf{9 . 3 5 \%}$ & $\mathbf{1 4 . 4 9 \%}$ & $\mathbf{1 0 . 4 3 \%}$ & $\mathbf{1 1 . 1 8 \%}$ & $\mathbf{1 3 . 4 2 \%}$ \\
\hline $25-$ & $\mathbf{1 7 . 9 2 \%}$ & $\mathbf{1 9 . 8 1 \%}$ & $\mathbf{1 8 . 1 6 \%}$ & $\mathbf{2 6 . 8 9 \%}$ & $\mathbf{1 9 . 1 3 \%}$ & $\mathbf{1 8 . 6 6 \%}$ \\
\hline $30-$ & $\mathbf{2 0 . 0 9 \%}$ & $\mathbf{1 8 . 9 0 \%}$ & $\mathbf{1 6 . 2 8 \%}$ & $\mathbf{3 2 . 9 1 \%}$ & $\mathbf{1 8 . 8 1 \%}$ & $\mathbf{2 2 . 6 4 \%}$ \\
\hline $35-$ & $\mathbf{1 9 . 2 7 \%}$ & $\mathbf{1 1 . 0 3 \%}$ & $\mathbf{2 0 . 9 7 \%}$ & $\mathbf{3 4 . 3 2 \%}$ & $\mathbf{2 3 . 4 4 \%}$ & $\mathbf{2 9 . 2 4 \%}$ \\
\hline $40-$ & $\mathbf{1 8 . 3 8 \%}$ & $\mathbf{1 6 . 1 6 \%}$ & $\mathbf{2 1 . 1 7 \%}$ & $\mathbf{3 6 . 6 1 \%}$ & $\mathbf{2 9 . 3 1 \%}$ & $\mathbf{2 9 . 3 7 \%}$ \\
\hline $45-$ & $\mathbf{1 9 . 4 9 \%}$ & $\mathbf{1 7 . 9 1 \%}$ & $\mathbf{2 3 . 1 4 \%}$ & $\mathbf{4 7 . 5 8 \%}$ & $\mathbf{3 3 . 7 3 \%}$ & $\mathbf{3 5 . 2 2 \%}$ \\
\hline
\end{tabular}

The results found that about $80 \%$ of women lived in rural areas. Over $90 \%$ of women stated that a Primary Health Care (PHC) facility was available in their areas. Only one fifth of the women indicated they were covered by some form of health insurance. Nearly $70 \%$ of women in this sample were ever married; of whom $26.39 \%$ were married before the age of 18 (Table 2). 
Table (2): Socio-demographic characters of women 15-49 years in the study sample

\begin{tabular}{|l|l|c|c|}
\hline Socio-demographic actors & & Number & $\%$ \\
\hline \multirow{4}{*}{ Region } & Upper Egypt & 8695 & $56.9 \%$ \\
\cline { 2 - 4 } & Lower Egypt & 6584 & $43.1 \%$ \\
\hline \multirow{5}{*}{ Governorate } & Sharkeya & 2917 & $19.1 \%$ \\
\cline { 2 - 4 } & Ismailia & 799 & $5.2 \%$ \\
\cline { 2 - 4 } & Beheira & 2868 & $18.8 \%$ \\
\cline { 2 - 4 } & Menya & 2760 & $18.1 \%$ \\
\cline { 2 - 4 } & Assiut & 2993 & $19.6 \%$ \\
\cline { 2 - 4 } & Sohag & 2942 & $19.3 \%$ \\
\hline \multirow{2}{*}{ Residence } & Rural & 12293 & $80.5 \%$ \\
\cline { 2 - 4 } & Urban & 2986 & $19.5 \%$ \\
\hline \multirow{2}{*}{ Ever married } & No & 4594 & $30.1 \%$ \\
\cline { 2 - 4 } & Yes & 10685 & $69.9 \%$ \\
\hline
\end{tabular}

Early age of marriage was significantly more common in rural areas than in urban areas; and in Upper Egypt than Lower Egypt. Women who did not complete their secondary education were nearly 5 times more likely to be married early compared to those who attained secondary education or higher. The odds of early marriage were higher among women in the lowest wealth quintiles and those who didn't have jobs. More than $30 \%$ of consanguineous marriages occurred when a woman was below the age of 18 compared to $23.7 \%$ of nonconsanguineous marriages with statistical significant difference $(\mathrm{P}<0.05$-Table 3$)$.

Table( 3): Socio-demographic factors associated with early marriage

\begin{tabular}{|c|c|c|c|c|c|c|c|}
\hline \multirow{2}{*}{\multicolumn{2}{|c|}{$\begin{array}{l}\text { Socio-demographic } \\
\text { Factors }\end{array}$}} & \multirow{3}{*}{$\begin{array}{l}\text { Total } \\
4805 \\
\end{array}$} & \multicolumn{2}{|c|}{ Early married } & \multirow{3}{*}{$\begin{array}{c}\text { OR } \\
1 \\
\end{array}$} & \multicolumn{2}{|c|}{$95 \%$ CI } \\
\hline & & & \multirow{2}{*}{$\frac{\mathrm{N}}{1033}$} & \multirow{2}{*}{$\begin{array}{c}\text { Row N \% } \\
21.5 \%\end{array}$} & & \multirow[t]{2}{*}{ LL } & \multirow[t]{2}{*}{ UL } \\
\hline Region & Lower Egypt & & & & & & \\
\hline & Upper Egypt & 5880 & 1787 & $30.4 \%$ & $1.59 *$ & 1.46 & 1.74 \\
\hline \multirow[t]{2}{*}{ Residence } & Urban & 1950 & 317 & $16.3 \%$ & 1 & & \\
\hline & Rural & 8735 & 2503 & $28.7 \%$ & $2.07 *$ & 1.82 & 2.35 \\
\hline \multirow[t]{2}{*}{ Education } & $\begin{array}{l}\text { Secondary } \\
\text { or higher }\end{array}$ & 4577 & 504 & $11.0 \%$ & 1 & & \\
\hline & $\begin{array}{l}\text { Less than } \\
\text { secondary }\end{array}$ & 6023 & 2295 & $38.1 \%$ & $4.98 *$ & 4.47 & 5.53 \\
\hline \multirow[t]{2}{*}{ Consanguinity } & None & 6891 & 1635 & $23.7 \%$ & 1 & & \\
\hline & Yes & 3794 & 1185 & $31.2 \%$ & $1.46^{*}$ & 1.34 & 1.60 \\
\hline \multirow[t]{2}{*}{ Work status } & $\begin{array}{l}\text { Working for } \\
\text { cash }\end{array}$ & 1102 & 120 & $10.9 \%$ & 1 & & \\
\hline & Not working & 9583 & 2700 & $28.2 \%$ & $3.21 *$ & 2.64 & 3.90 \\
\hline \multirow[t]{2}{*}{ Wealth } & 4-5 quintiles & 4177 & 722 & $17.3 \%$ & 1 & & \\
\hline & 1-3 quintiles & 6508 & 2098 & $32.2 \%$ & $2.28 *$ & 2.07 & 2.51 \\
\hline
\end{tabular}

* Statistically significant difference using Chi squared test $\mathrm{P}<0.05$.

The mean (standard deviation) number of children per woman among early married women was 3.59 (1.83) compared to 2.82 (1.54) among women married at the age of 18 years or higher. The difference was statistically significant $(\mathrm{P}<$ 0.001). 
Regarding reproductive health services provision during the last pregnancy; within the period of 3 years prior to the survey. 1737 women responded (389 early married and 1348 married $\geq 18$ years). About $94 \%$ of both groups received ANC during the last pregnancy. The median number (IQR) of ANC visits among early marries women was 5 (4-8) compared to 5
(4-9) among women married $\geq 18$ years. The difference was not statistically significant $(P=0.965)$. However, early married women were less likely to receive Iron and Folic acid and tetanus vaccination during pregnancy with statistical significant difference $(\mathrm{p}<0.05)$ in iron and folic acid intake (Table 4).

Table (4): Comparison between ante-natal care (ANC) services -received during the last pregnancy- by age of marriage

\begin{tabular}{|c|c|c|c|c|c|c|}
\hline \multirow{2}{*}{$\begin{array}{l}\text { Type of ANC } \\
\text { service }\end{array}$} & \multirow{2}{*}{$\begin{array}{l}\text { Age of } \\
\text { Marriage }\end{array}$} & \multirow[t]{2}{*}{$\mathrm{N}$} & \multirow[t]{2}{*}{ Row \% } & \multirow[t]{2}{*}{ OR } & \multicolumn{2}{|c|}{$95 \%$ CI for OR } \\
\hline & & & & & LL & UL \\
\hline \multirow[t]{2}{*}{ Tetanus vaccination } & $\geq 18$ & 1225 & $90.88 \%$ & 1 & & \\
\hline & $<18$ & 344 & $88.43 \%$ & 0.77 & 0.53 & 1.10 \\
\hline \multirow{2}{*}{ Iron } & $\geq 18$ & 1183 & $87.76 \%$ & 1 & & \\
\hline & $<18$ & 323 & $83.03 \%$ & $0.68 *$ & 0.50 & 0.93 \\
\hline \multirow[t]{2}{*}{ Folic acid } & $\geq 18$ & 1103 & $81.82 \%$ & 1 & & \\
\hline & $<18$ & 290 & $74.55 \%$ & $0.65^{*}$ & 0.50 & 0.85 \\
\hline
\end{tabular}

* Statistically significant difference using Chi squared test $\mathrm{P}<0.05$

Early married $\mathrm{N}=389$, Married $\geq 18 \mathrm{~N}=1348$

Concerning intra-partum and postpartum care. 1524 women responded (351 early married and 1173 married $\geq 18$ years). Early married women were more likely to have a vaginal delivery at home.
However, there was no statistically significant difference regarding having a trained birth attendant or post-partum care between early married women and those married $\geq 18$ years (Table 5).

Table (5): Comparison between intra-partum and post-partum care to age of marriage

\begin{tabular}{|c|c|c|c|c|c|c|}
\hline \multirow{2}{*}{ Type of care } & \multirow{2}{*}{$\begin{array}{l}\text { Age of } \\
\text { marriage }\end{array}$} & \multirow{2}{*}{$\mathrm{N}$} & \multirow{2}{*}{$\%$} & \multirow{2}{*}{ OR } & \multicolumn{2}{|c|}{$95 \%$ CI for OR } \\
\hline & & & & & LL & $\mathrm{UL}$ \\
\hline \multirow{2}{*}{$\begin{array}{l}\text { Vaginal } \\
\text { delivery }\end{array}$} & Married $\geq 18$ & 501 & $42.7 \%$ & 1 & & \\
\hline & Married <18 & 175 & $49.9 \%$ & $1.33^{*}$ & 1.05 & 1.69 \\
\hline \multirow{2}{*}{$\begin{array}{l}\text { Health care } \\
\text { facility }\end{array}$} & Married $\geq 18$ & 1031 & $87.9 \%$ & 1 & & \\
\hline & Married <18 & 293 & $83.5 \%$ & $0.70 *$ & 0.50 & 0.97 \\
\hline \multirow{2}{*}{$\mathrm{HCW}$} & Married $\geq 18$ & 1122 & $95.7 \%$ & 1 & & \\
\hline & Married <18 & 327 & $93.2 \%$ & 0.62 & 0.38 & 1.02 \\
\hline \multirow{2}{*}{$\begin{array}{l}\text { Post-partum } \\
\text { care }\end{array}$} & Married $\geq 18$ & 921 & $78.5 \%$ & 1 & & \\
\hline & Married $<18$ & 271 & $77.2 \%$ & 0.93 & 0.70 & 1.23 \\
\hline
\end{tabular}

*Statistically significant difference using Chi squared test $\mathrm{P}<0.05$. Early married $\mathrm{N}=351$, Married $\geq 18 \mathrm{~N}=$ 1173

Regarding contraceptive use, 4399 married women responded (1029 early married and 3370 married $\geq 18$ ). No statistically significant difference was observed between early married women and women married $\geq 18$ years regarding the percentage of current use of contraceptives $(57.82 \%$ and $58.01 \%$ respectively) or the percentage of unmet need (16.13\% and $17.24 \%$ respectively).

Ever married women were asked about receiving reproductive health education. 
Early married women were less likely to have received health education about reproductive health aspects including the hazards of early age of marriage. Family planning education was the only exception where no statistically significant difference was observed. Women who had a history of a past pregnancy were asked about the adverse birth outcomes, including history of abortion, still birth as well as neonatal, post-neonatal and mortality in preschool age. 2368 early married women and 6229 women married $\geq 18$ years responded to these questions. The results showed the unadjusted Odds Ratios (ORs) that show that early married women had significantly higher chances of having adverse birth outcomes and infant mortality. However, when ORs were adjusted for region, residence, wealth, consanguinity and education, it appeared that early marriage per se was significantly associated with still births only (Table 6).

Table (6): Reproductive health education, adverse birth outcomes and infant mortality in relation to age of marriage

\begin{tabular}{|c|c|c|c|c|c|c|}
\hline \multirow{2}{*}{$\begin{array}{l}\text { Health } \\
\text { education }\end{array}$} & \multirow{2}{*}{$\begin{array}{l}\text { Age of } \\
\text { marriage }\end{array}$} & \multirow{2}{*}{$\mathrm{N}$} & \multirow{2}{*}{$\%$} & \multirow{2}{*}{ OR } & \multicolumn{2}{|c|}{$95 \% \mathrm{CI}$ for OR } \\
\hline & & & & & LL & UL \\
\hline \multirow{2}{*}{ Family planning } & $\geq 18$ & 5248 & $93.6 \%$ & 1 & & \\
\hline & $<18$ & 1953 & $93.2 \%$ & 0.93 & 0.76 & 1.14 \\
\hline \multirow{2}{*}{ Early marriage } & $\geq 18$ & 4662 & $83.2 \%$ & 1 & & \\
\hline & $<18$ & 1643 & $78.4 \%$ & $0.73^{*}$ & 0.65 & 0.83 \\
\hline \multirow{2}{*}{ FGM hazards } & $\geq 18$ & 4713 & $84.1 \%$ & 1 & & \\
\hline & $<18$ & 1652 & $78.9 \%$ & $0.71 *$ & 0.62 & 0.80 \\
\hline \multirow{2}{*}{$\begin{array}{l}\text { Safe } \\
\text { motherhood }\end{array}$} & $\geq 18$ & 4509 & $80.5 \%$ & 1 & & \\
\hline & $<18$ & 1621 & $77.4 \%$ & $0.83 *$ & 0.74 & 0.94 \\
\hline \multirow{2}{*}{$\begin{array}{l}\text { Male } \\
\text { participation }\end{array}$} & $\geq 18$ & 4427 & $79.0 \%$ & 1 & & \\
\hline & $<18$ & 1566 & $74.7 \%$ & $0.79 *$ & 0.70 & 0.89 \\
\hline \multirow{2}{*}{ Breast feeding } & $\geq 18$ & 5333 & $95.2 \%$ & 1 & & \\
\hline & $<18$ & 1962 & $93.7 \%$ & $0.75^{*}$ & 0.61 & 0.93 \\
\hline \multirow{3}{*}{ Abortion } & $\geq 18$ & 333 & $5.35 \%$ & 1 & & \\
\hline & $<18$ & 173 & $7.31 \%$ & $1.40^{*}$ & 1.15 & 1.69 \\
\hline & Adjusted OR ${ }^{1}$ & & & 1.19 & 0.96 & 1.47 \\
\hline \multirow{3}{*}{ Still birth } & $\geq 18$ & 91 & $1.46 \%$ & 1 & & \\
\hline & $<18$ & 71 & $3.00 \%$ & $2.09^{*}$ & 1.52 & 2.85 \\
\hline & Adjusted OR & & & $1.57^{*}$ & 1.12 & 2.21 \\
\hline \multirow{3}{*}{$\begin{array}{l}\text { Neonatal } \\
\text { mortality }\end{array}$} & $\geq 18$ & 173 & $2.78 \%$ & 1 & & \\
\hline & $<18$ & 93 & $3.93 \%$ & $1.43^{*}$ & 1.11 & 1.85 \\
\hline & Adjusted OR & & & 1.19 & 0.88 & 1.60 \\
\hline \multirow{3}{*}{$\begin{array}{l}\text { Post- Neonatal } \\
\text { mortality }\end{array}$} & $\geq 18$ & 32 & $0.51 \%$ & 1 & & \\
\hline & $<18$ & 24 & $1.01 \%$ & $1.98^{*}$ & 1.17 & 3.37 \\
\hline & Adjusted OR & & & 1.51 & 0.86 & 2.66 \\
\hline \multirow{3}{*}{$\begin{array}{l}\text { Mortality in pre- } \\
\text { school age }\end{array}$} & $\geq 18$ & 29 & $0.47 \%$ & 1 & & \\
\hline & $<18$ & 17 & $0.72 \%$ & 1.55 & 0.85 & 2.82 \\
\hline & Adjusted OR & & & 0.94 & 0.51 & 1.72 \\
\hline
\end{tabular}

*Statistically significant difference using Chi squared test $\mathrm{P}<0.05 \nmid \mathrm{OR}$ adjusted for region, residence, education, consanguinity and wealth. GEE binary logistic regression was used with inverse propensity score weighting.

Early married $N=2095$, Married $\geq 18 \mathrm{~N}=5604$ 


\section{DISCUSSION}

Early marriage of girls is rooted in developing countries. Nevertheless, the situation is varied greatly by country and by regions within each country (Farid et al., 2015). Several legislative and programmatic frameworks have been designed to prevent early marriage but their implementation is not fully achieved (UNICEF, 2001). Egypt had increased the legal age for marriage to 18 years by the Egyptian law No.126 of 2008 (The National council for Childhood and Motherhood, 2008) that prohibited the registration of marriage for those who are under 18 years of age. It was expected that a decline in the number of early marriages would occur. However, the implementation of the law is facing multiple barriers and community resistance.

The current study was conducted on 15279 woman aged 15-49 years from both upper and lower Egypt, revealed that $26.39 \%$ of ever married females got married before the age of 18. Egypt DHS 2014 has found that Almost one quarter of sampled women aged 15-49 years are married by age 18 and more than $10 \%$ of young women age 15-19 have begun childbearing: $7 \%$ have had a child and $4 \%$ were pregnant at the time of the DHS concluding that teenage childbearing is more common in rural areas $(14 \%)$ than urban areas $(5 \%)(E D H S, 2014)$ and this matches with the current study findings where early age of marriage was higher in rural than in urban areas and in upper more than lower Egypt, and with the study conducted in 2014 in Menoufia governorate (Lower Egypt) and Souhag governorate (Upper Egypt) where child marriage was higher in Souhag reaching $25.4 \%$ and lower in Menoufia reaching $19.4 \%$. Some attributed this behavior to the context of child marriage that is mostly linked to the context of poverty, cultural and religious beliefs (Elden and Mosleh, 2015).

Educational level has proved to have its effect not only on the prevalence of such phenomenon but also on the age of first pregnancy and number of children. $E D H S$, 2014, found that women with no education marry the earliest, at a median age of 18.6, compared to 22.3 among women with secondary complete or higher education. Women from the wealthiest households marry more than 4 years later than women in the poorest households and that women age 25-49 had their first birth at a median age of 22.6. Women with no education have their first birth three years earlier than women with secondary of higher education (EDHS, 2014). Similarly are the results of the current study, which found that women with less than secondary education were nearly 5 times more likely to be married early compared to those who attained secondary education or higher. Also the number of children per woman among early married women was 3.59 (1.83) compared to 2.82 (1.54) among women married at the age of 18 years or older.

Consanguineous marriage has been found to be closely linked to child marriage. A study was conducted by Shawkya et al, 2011 in three governorates in Egypt - Cairo, Assuit and Souhag reflected properly the prevalence of consanguinity that was still high in Egypt (35.3\%), especially among first cousins $(86 \%)$ and that it was associated with 
decreased age of marriage and low educational level (Shawkya et al., 2011). This was also proved in the current study, in which more than $30 \%$ of consanguineous marriages occurred when a woman was below the age of 18 compared to $23.7 \%$ of nonconsanguineous marriages.

Child marriage was also proved to have its effect on both the woman and her offspring later. Births resulting from child marriages are said to be "too soon, too close, or too many" (UNFPA, 2006). The study revealed that early married women had significantly higher chances of having adverse birth outcomes and infant mortality including stillbirth. Similarly the studies conducted by Adhikariet al ,2009 and Raji et al, proved that early married adolescent girls' are more likely than adult married women to report complications in pregnancy and unplanned pregnancies with greater experiences of miscarriage and stillbirth (Adhikari et al., 2009 and Raj et al., 2010).

Many studies had shown that awareness of family planning and maternal care utilization is lower among the women who married at early age (Gold et al., 2010 and Nasrullah et al., 2014), Also the current study found that early married women were less likely to have received health education about reproductive health aspects including the hazards of early age of marriage, however there was no significant difference between those who married before 18 years and those after regarding mean number of antenatal care visits yet early married women were less likely to receive Iron and Folic acid during pregnancy as a routine supplement in ANC.

\section{CONCLUSION and RECOMMENDATION}

Child marriage behavior has been linked to other unhealthy behavior like consanguinity, lower level of education and probably other unwanted behaviors like high fertility and higher rate of pregnancy and delivery complications. An integrated program tackling all these health issues will be of value in reducing this behavior and improving women health.

\section{ACKNOWLEDGEMENT}

The researchers acknowledge receiving funding from the National Population Council, which was used in carrying out this study, in 2017.

\section{REFERENCES}

1. Adhikari $\mathbf{R}$, Soonthorndhada $K$ and Prasartkul P (2009): Correlates of unintended pregnancy among currently pregnant married women in Nepal. BMC International Health 10: 1-10.

2. Egypt Demographic and Health Survey 2014 (EDHS 2014): Ministry of Health and Population/Egypt, El-Zanaty and Associates/Egypt, and ICF International.

3. Elden NM and Mosleh H (2015): Impact of Change in Law on Child Marriage in Egypt A Study in Two Egyptian Governorates. The Egyptian Journal of Community Medicine 33: 4.

4. Farid AW, Rusli M., Ismail N., Ghrayeb NF and Rifai A. (2015): Prevalence of Early Marriage among Women in Rural Palestinian Community: A Cross-Sectional Study, International Medical Journal 22 (4), p. 291 294.

5. Gold KJ, Sen A and Hayward RA (2010): Marriage and cohabitation outcomes after pregnancy loss. Pediatrics 125: e1202-e1207. 
6. Malé C. and Wodon Q. (2016): B asic profile of child marriage in Egypt. HNPGP Knowledge Brief, March 2016.

7. Nasrullah M, Muazzam S, Bhutta ZA and Raj A (2014): Girl child marriage and its effect on fertility in Pakistan: Findings from Pakistan demographic and health survey, 2006-2007. Matern Child Health J 18: 534543.

8. Raj A, Saggurti N, Winter M, Labonte A and Decker MR (2010): The effect of maternal child marriage on morbidity and mortality of children under 5 in India: crosssectional study of a nationally representative sample. BMJ 340: b4258.

9. Roudi-Fahimi F and Ibrahim S (2014): Ending child marriage in the Arab region Population Reference Bureau 2013.

10. Shawkya R.M. El-Awady M.Y., Elsayed S. $M$ and Hamadan G.E. (2011): Consanguineous matings among Egyptian population. Egyptian Journal of Medical Human Genetics. 12(2), 157-163.

11. The National council for Childhood and Motherhood (2008): Law no 12 of 1996 formulating the child law (amended by law no 126 of 2008).
12. United Nations Population Fund. Marriage and the family [cited 2006 Aug 8].

13. United Nations Population Fund. (2012): Marrying Too Young, End Child Marriage New York: UNFPA.

14. UNFPA. State of world population. (2005). Child marriage fact sheet.

15. United Nations Children's Fund (UNICEF 2005). Early Marriage: A Harmful Traditional Practice: A Statistical Exploration. UNICEF: New York,

16. UNICEF. Early marriage, child spouses (2001): Innocent Digest no 7 March 2001.

17. Women and Children Legal Research Foundation WCLRF (2008): Early Marriage in Afghanistan. Women and Children Legal Research Foundation (WCLRF 2008).

18. World Medical Association (2013). World Medical Association Declaration of HelsinkiEthical Principles for Medical Research Involving Human subjects JAMA, 310(20):2191-4. 
زواج الأطفال: سلوك خطير يمارس فى محافظات مصر النامية

داليا جابر سوس، مها محمد الجعفرى، مها مجدى وهدان، غادة أسامة واصف، سالي عادل حكيم، وفاء محمد حسين، عمروحسن*، محمد يحيى العوضى، ميرفت راضى، وجيدة عبد الرحمن أنور

قسم المجتمع، البيئة والطب المهني، كلية الطب، جامعة عين شمس، والمجلس القومى للسكان*

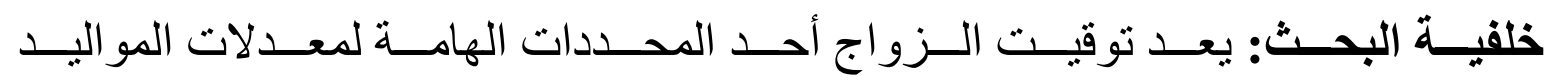
و الوضــــع الصــــي لكــل مـــن الأمهـــات و الأطفـــال الرضــــع. ويعتبـــر زواج الأطفــال قضــية هامــة مــن قضـــايا التنمبــة الرئيســبة التــي تــؤثر علــى الفتيــات

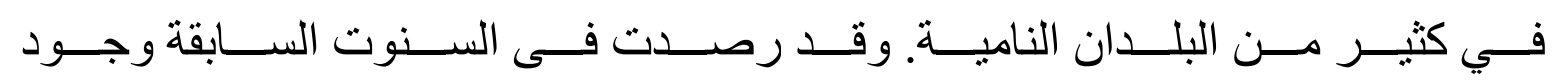

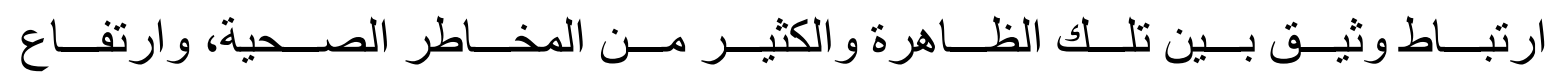
معدلات الخصوبة، و انخفاض التحصبل التعليمي للسيدات.

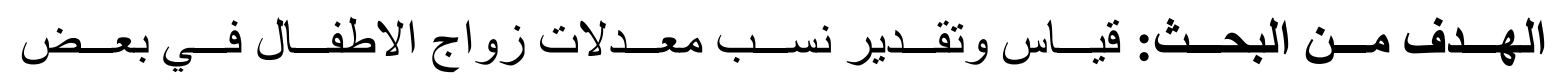

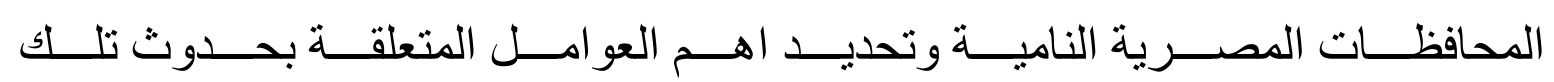
الظاهرة.

الأ شــخاص و طــرق البحــث: تعـــد هــذه الدر اســـة جــز عا مــن در اســـة و اســعة،

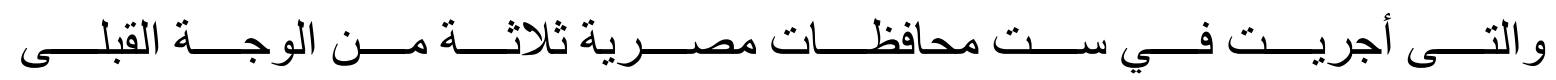
(ســـو هاج و أســـيوط و المنيــا) و ثلاثــة مـــن الوجــة البحــرى (الثـــرقية، البحيــرة

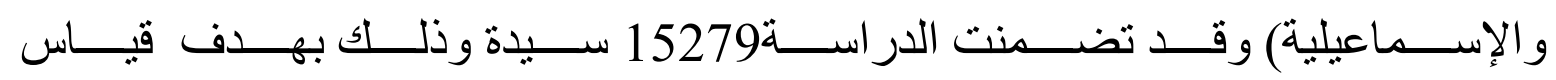

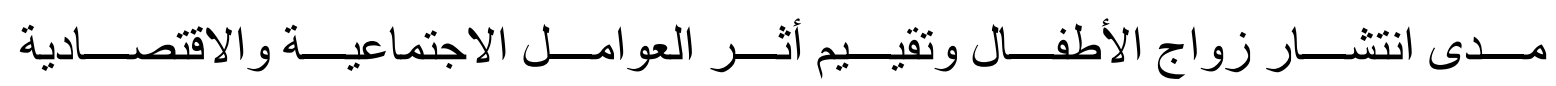

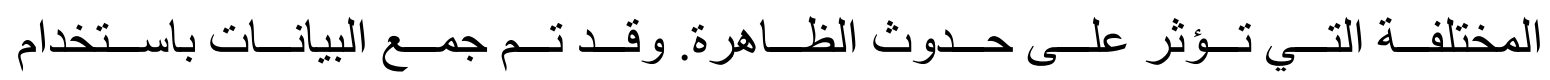

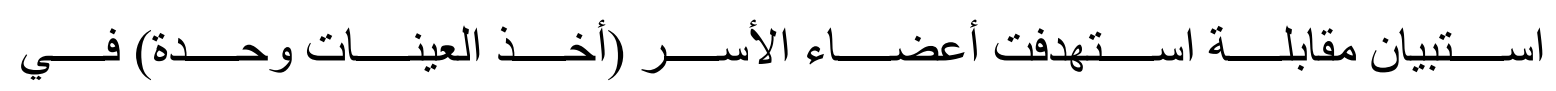
المحافظات المختارة. 


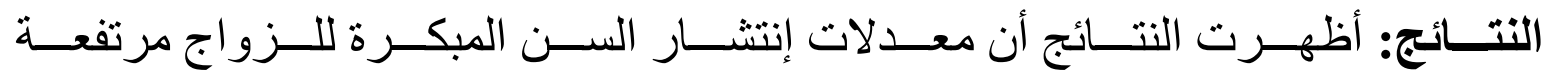

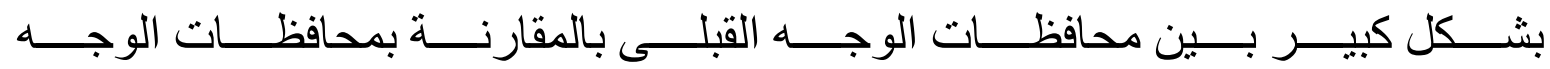

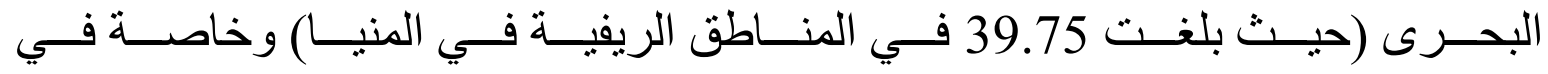

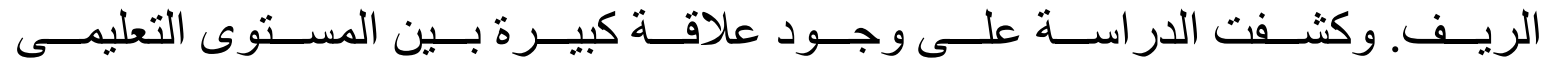

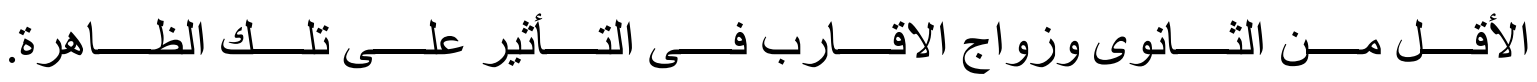

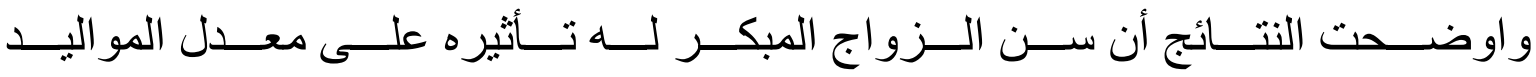

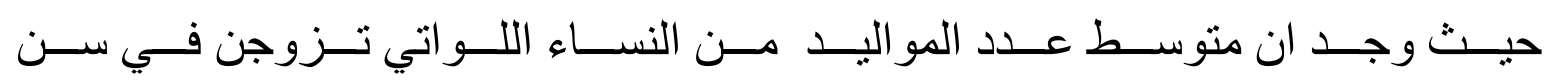
أقل من 18 عاما هو 3.59.

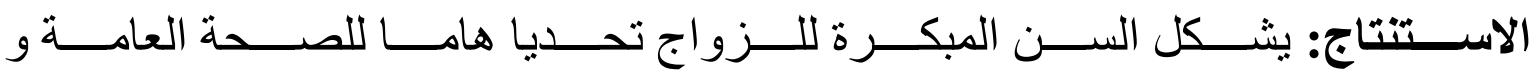

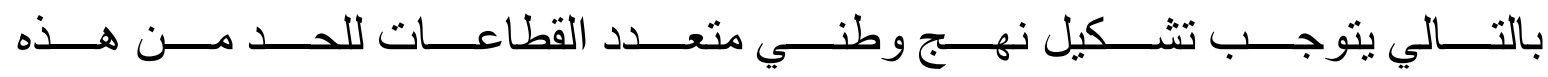
الظاهرة. 